\title{
Enhancement of domoic acid neurotoxicity on Diptera larvae bioassay by marine fungal metabolites
}

\author{
Nicolas Ruiz ${ }^{\mathrm{a}}$, Karina Petit ${ }^{\mathrm{a}}$, Marieke Vansteelandt ${ }^{\mathrm{a}}$, Isabelle Kerzaon ${ }^{\mathrm{a}}$, Joseph Baudet ${ }^{\mathrm{a}}$, Zouher \\ Amzil $^{b}$, Jean-François Biard ${ }^{a}$, Olivier Grovel ${ }^{a}$ and Yves François Pouchus ${ }^{a,{ }^{*}}$ \\ a University of Nantes, Faculty of Pharmacy, MMS - EA 2160, F-44000 Nantes, France
b IFREMER, Phycotoxins laboratory, F-44000 Nantes, France \\ *: Corresponding author: Pouchus Y. F., Tel.: +33 2404128 70; fax: +33 2404128 58, email address : yves- \\ francois.pouchus@univ-nantes.fr
}

\begin{abstract}
:
Peptaibols are small linear fungal peptides which are produced in the marine environment. They exhibit neurotoxicity by forming pores in neuronal membranes. This work describes their combine effect with domoic acid, a neurotoxic phycotoxin, on Diptera larvae. The Acute toxicity bioassay on this biological model was tested with a panel of different toxins (microbial, algal or fungal). It allowed the discrimination of neurotoxins and non-neurotoxic toxins, and an evaluation of the toxicity level (MED and $\left.E D_{50}\right)$ which were correlated with published $\mathrm{LD}_{50}$ in mice for neurotoxins tested. The highest activities on this test were found for $\mathrm{Na}^{+}$channel blockers tetrodotoxin $\left(E D_{50}=0.026 \mathrm{mg} / \mathrm{kg}\right)$ and saxitoxin $\left(E D_{50}=0.18 \mathrm{mg} / \mathrm{kg}\right.$ ). Domoic acid was less active with an $\mathrm{ED}_{50}=7.6 \mathrm{mg} / \mathrm{kg}$. For synergism study, longibrachin-A-I, a 20-mer peptaibol isolated from cultures of a marine-derived strain of Trichoderma longibrachiatum Rifai was chosen. Bioassay results confirmed its neuroactivity. Its level of toxicity $\left(\mathrm{ED}_{50}=270 \mathrm{mg} / \mathrm{kg}\right)$ was lower than those of phycotoxins tested but higher than mycotoxin ones. Injected together, Iongibrachin-A-I and domoic acid exhibited an increase of their activities. With doses of longibrachin-A-I below its Minimal Effective Dose (MED), the synergism factor which expresses the enhancement of domoic acid toxicity could reach 34.5. Both domoic acid and longibrachin-A-I are acting on ion channels and pores in neuronal membranes which contribute to the intake of $\mathrm{Ca}^{2+}$ into cells.
\end{abstract}

Keywords: Domoic acid; Peptaibol; Synergism; Neurotoxicity; Marine-derived fungal metabolite; Diptera larvae bioassay 


\section{Introduction}

In the beginning of the 90's, several unexplained toxicity episodes of cultured shellfish took place along the French coast (Amzil et al., 1996). Neither known toxins nor chemical pollutants could be found in sufficient amounts to explain observed toxicities. A new hypothesis was then established involving a fungal origin. For that purpose, fungi were isolated from shellfish and sediments, and tested for their toxicities (Sallenave-Namont et al., 2000). Several strains of the genus Trichoderma exhibited a high level of acute toxicity on Diptera larvae, and accumulation of their toxic metabolites by mussel in laboratory conditions was demonstrated to be possible (Sallenave et al., 1999). Toxic metabolites produced by Trichoderma sp. strains were identified as peptaibols, small linear peptides, with a length ranging from 11 to 20 amino acid residues, which create ion channels in postsynaptic membranes (Landreau et al., 2002 ; Mohamed- Benkada et al., 2006 ; Ruiz et al., 2007). Recently, peptaibols have been identified in natural sediment and shellfish samples, indicating the effectiveness of the development of Trichoderma sp. in the marine environment and their ability to contaminate shellfish (Poirier et al., 2007a).

Previously, Trichoderma sp. strains had already been isolated from shellfish of the area of Prince Edward Island (Canada) (Brewer et al., 1993). This work was completed after an atypical episode of human intoxication by cultured blue mussels (Mytilus edulis) which led to the identification of domoic acid as the causative agent of the toxicity (Wright et al., 1989). This neurotoxic amino acid was shown to be produced by the pennate diatom Pseudo-nitzshia pungens (Bates et al., 1989; Smith, 1993). It is a neurotransmitter amino acid that binds to one of the synaptic receptors of glutamic acid known as the kainic-acid receptor. It allows sodium ions to enter the postsynaptic membrane, inducing an increase in the permeability of calcium ions that leads to cell dysfunction or death, producing head-ache, confusion, disorientation and loss of memory (Hampson et al., 1992; Brown and Nijjar, 1995; Hampson and Manolo, 1998; Pulido, 2008). This last symptom is the origin of the name of these intoxications which are called Amnesic Shellfish Poisonning (ASP).

Later on (1991-1993) various episodes of razor clam toxicity due to domoic acid were reported (Wekell et al., 1994). Surprisingly the toxicities observed were higher than those expected with the level of domoic acid contamination (Todd, 1993). The presence of another compound enhancing domoic acid toxicity could be suspected. A first proposal was made by Novelli et al. (1992a and 1992b) who demonstrated that, in neuronal cultures, domoic acid-containing mussel extracts were more toxic than pure domoic acid. This was the result of its potentiation by glutamic and aspartic acids present in mussel tissue. Nevertheless the synergism factor which represents the increase of toxicity of domoic acid did not exceed 3.5. This was less than the difference described by Todd (1993).

Considering that Trichoderma sp. strains can contaminate shellfish and are able to produce neurotoxic peptaibols, it could be interesting to study the combined effect of domoic acid and peptaibols on a neurotoxicity bioassay. For that purpose, acute toxicity on Diptera larvae could be appropriate as it has been demonstrated to be a suitable tool for monitoring neurotoxic compounds (Zdarek and Fraenkel, 1987). To evaluate if this bioassay was adapted for the present study, various marine and fungal toxins were tested before evaluating the combined effects of domoic acid and longibrachin-A-I, one of the long peptaibols (20 residues) produced by marine-derived strains of Trichoderma longibrachiatum Rifai and observed as a contaminant in natural marine samples (Poirier et al., 2007a).

\section{Material and Methods}

\subsection{Control toxins and peptaibols}

Domoic acid, okadaic acid, brevetoxin $\mathrm{PbT} x 2$, saxitoxin, citrinin, fumonisin B1, ochratoxin A, patulin, Bnitropropionic acid, gliotoxin and tetrodotoxin were obtained from Sigma Chemical Co. (St. Louis, MO). Ryanodin was obtained from Latoxan (Rosans, France). Penicillic acid was purified by flash chromatography and selective crystallization from solid cultures of a marine strain of Penicillium sp. (strain MMS 351). Communesin B was obtained by isolation from solid cultures of a marine strain of Penicillium expansum Link ex Gray (strain MMS 42) according to the protocol described in Kerzaon et al. (in press). Longibrachin-A-I was isolated from solid cultures of a marine-derived strain of Trichoderma longibrachiatum Rifai (strain MMS 151). Extraction and purification were performed according to the method described by Poirier et al. (2007b). Identification and purity control of isolated toxins and peptaibols were carried out by mass spectrometry using an electrospray ionization-ion trap mass spectrometer (ESI-IT/MS) (LCQ, Finnigan, Thermo Separation Products, San Jose, CA, USA).

\subsection{Acute toxicity test on Diptera larvae}

\subsubsection{Larvae}

All the assays were performed with larvae of the blue fly Calliphora vomitoria L. which were at the last stage before pupariation. The larvae were obtained from fishing supply stores. 


\subsubsection{Test solutions}

Substances to be tested were dissolved in distilled water, using organic solvents in the following proportions: aqueous $\mathrm{MeOH}$ or DMSO $15 \%$ and aqueous $\mathrm{EtOH} 5 \%$ maximum (dichloromethane, acetonitrile, and ethyl acetate were not used because of their toxicity for the animal). Penicillic acid was dissolved in $0.01 \mathrm{~N} \mathrm{NaOH}$. Ranges of dilutions were prepared with concentrations depending on the level of toxicity of the different toxins.

\subsubsection{The assay}

Test solutions were injected at a rate of $0.1 \mu \mathrm{L}$ per mg of larval body weight (e.g. $7 \mu \mathrm{L}$ injected for $70 \mathrm{mg}$ larvae) using a $10 \mu \mathrm{L}$ microsyringe with a thin hypodermic needle (Hamilton, Bonaduz, Switzerland). The needle was inserted into the ventral side at the level of the last abdominal segment and penetrated a third of the animal's length before the product was slowly injected. The time $(T)$ required for immobilization of the animal after injection was measured in seconds. A minimal $\mathrm{T}$ value of $5 \mathrm{~s}$ was used for immediate immobilization or with a very small delay. If no immobilization occurred after $10 \mathrm{~min}(600 \mathrm{~s})$, the test was considered negative. Three replicates were tested for each dose.

\subsubsection{Results expression}

To represent the activity/dose relation, the curve 500/T = $f$ ((injected concentration) was drawn (Fig 1). The Minimal Effective Dose (MED) is the lowest concentration tested which produces an immobilization of larvae. The mid Effective Dose $\left(E D_{50}\right)$ is determined at mid-slope and the Maximal Activity Level (MAL) is the maximal $500 / T$ ratio obtained for the toxin tested.

\subsection{Potentiation of domoic acid by constant added doses of longibrachin-A-I}

To study the potentiation of domoic acid by longibrachin-A-I, three sets of solutions containing both toxins were prepared and tested. Each set was prepared with series of dilutions (1/2) of domoic acid ranging from 4.9 to 62.5 $\mathrm{mg} / \mathrm{kg}$ and a constant concentration of longibrachin-A-I, 50, 150 and $250 \mathrm{mg} / \mathrm{kg}$ for set 1, 2 and 3 respectively.

\section{Results}

\subsection{Response of Diptera larvae to known non-protein toxins}

In order to use acute toxicity on Diptera larvae as a biological test for the detection and study of non-protein neurotoxins, various control toxins were tested. For each toxin, activity/dose curve was drawn and three values were determined: MED (Minimal Effective Dose) which is the first concentration producing an immobilization of the larvae, MAL (Maximal Activity Level) which is equal to 100 if an immediate ( $T \leq 5 \mathrm{~s}$ ) immobilization is obtained and $E D_{50}$ which represents the mean activity of the toxin. All values obtained are given in Table 1. 
Table 1. Response to the acute toxicity on Diptera larvae bioassay for pure toxins (neuroactive or with other toxicities) from different biological origins (bacterial, algal, fungal or plant). MED = Minimal Effective Dose, $\mathrm{ED}_{50}=$ mid Effective Dose, MAL = Maximal Activity Level. Data for LD $_{50}$ in mouse are from literature.

\begin{tabular}{|c|c|c|c|c|c|}
\hline \multirow[b]{2}{*}{ Toxin } & \multirow{2}{*}{\multicolumn{2}{|c|}{$\begin{array}{c}\text { Biological origin } L_{50} \text { in mouse } \\
\mathrm{mg} / \mathrm{kg}\end{array}$}} & \multicolumn{3}{|c|}{ Toxicity on Diptera larvae } \\
\hline & & & $\begin{array}{l}\mathrm{MED} \\
\mathrm{mg} / \mathrm{kg}\end{array}$ & $\begin{array}{c}D_{50} \\
\mathrm{mg} / \mathrm{kg} \\
\end{array}$ & $\begin{array}{c}\mathrm{MAL} \\
500 / \mathrm{T}\end{array}$ \\
\hline \multicolumn{6}{|l|}{$\begin{array}{l}\text { Neurotoxins and } \\
\text { neuroactive compounds }\end{array}$} \\
\hline Tetrodotoxin & bacterial & $0.011^{\mathrm{c}}$ & 0.00025 & 0.026 & 100 \\
\hline Saxitoxin & algal & $0.01^{d}$ & 0.05 & 0.18 & 100 \\
\hline Domoic acid & algal & $3.6^{\mathrm{e}}$ & 5.0 & 7.6 & $100^{a}$ \\
\hline Brevetoxin 2 & algal & $0.4^{\dagger}$ & 12.5 & 67 & 100 \\
\hline Patulin & fungal & $7.5^{\mathrm{g}}$ & 300 & 3800 & 100 \\
\hline beta-nitropropionic acid & fungal & $60.0^{\mathrm{h}}$ & 6500 & 10800 & 100 \\
\hline Ryanodin & plant & $0.1^{i}$ & 5000 & 44000 & 100 \\
\hline \multicolumn{6}{|l|}{ Other toxicities } \\
\hline Okadaic acid & algal & & 1 & 2.3 & 28 \\
\hline Communesin B & fungal & & 40 & 2400 & 50 \\
\hline Ochratoxin A & fungal & & 1000 & $>3700^{b}$ & $6^{\mathrm{b}}$ \\
\hline Penicillic acid & fungal & & $=3000^{\mathrm{b}}$ & b & $1^{b}$ \\
\hline Gliotoxin & fungal & & $-b$ & - & - \\
\hline Fumonisin & fungal & & $-b$ & - & - \\
\hline Citrinine & fungal & & $-b$ & - & - \\
\hline
\end{tabular}

The level of toxicity was highly variable for the different toxins tested. Diptera larvae showed adequate sensitivity to the marine phycotoxins, particularly tetrodotoxin (MED $=0.00025 \mathrm{mg} / \mathrm{kg}$ ) and saxitoxin (MED $=0.05 \mathrm{mg} / \mathrm{kg}$ ) which are both $\mathrm{Na}^{+}$channel blockers. For domoic acid, two commercial batches were tested. $\mathrm{ED}_{50}$ were quite similar for the two batches but with the second one, it was impossible to obtain the immediate immobilization, even with higher doses and the MAL stayed at a very low level $(M A L=5)$. Active mycotoxins were less effective than phycotoxins $\left(E D_{50}\right.$ nearly 1000 times higher). Nevertheless, for neuroactive compounds, MED on Diptera larvae and $\mathrm{LD}_{50}$ in mouse were correlated $(r=0.729)$.

Immediate immobilization (MAL $=100)$ was obtained with all neuroactive compounds. Non-neurotoxic substances could give a positive response on the test (e.g. okadaic acid) but never gave immediate immobilization, regardless of the dose used. These results confirmed that immediate immobilization should be specific of a neurotoxic activity and could be used to detect it.

\subsection{Activity of the marine peptaibol longibrachin-A-I}

Longibrachin-A-I has been identified from a culture of Trichoderma longibrachiatum (Leclerc et al., 1998). It had also been isolated from Gliocladium deliquescens with the name of Gliodesquin A (Brückner and Przybzlski, 1984) and from T. koningii with the name of Trichokonin-VI (Huang et al., 1996). As these names were synonyms and we chose to use longibrachin-A-I associated to $T$. longibrachiatum, which was the species of the strain used in this work. Longibrachin-A-I was chosen because it is one of the most common and abundant peptaibols produced by marine-derived strains of Trichoderma sp. and it had been observed in natural samples (Poirier et al., 2007a). Its activity on Diptera larvae was determined leading to an $E D_{50}=270 \mathrm{mg} / \mathrm{kg}$ with a MED $=250 \mathrm{mg} / \mathrm{kg}$ and a MAL = 100 (Fig. 1). Due to this MAL, longibrachin-A-I can be ranked among the compounds exhibiting neurotoxicity and its level of toxicity on that model was at least ten times higher than those of known mycotoxins tested. 


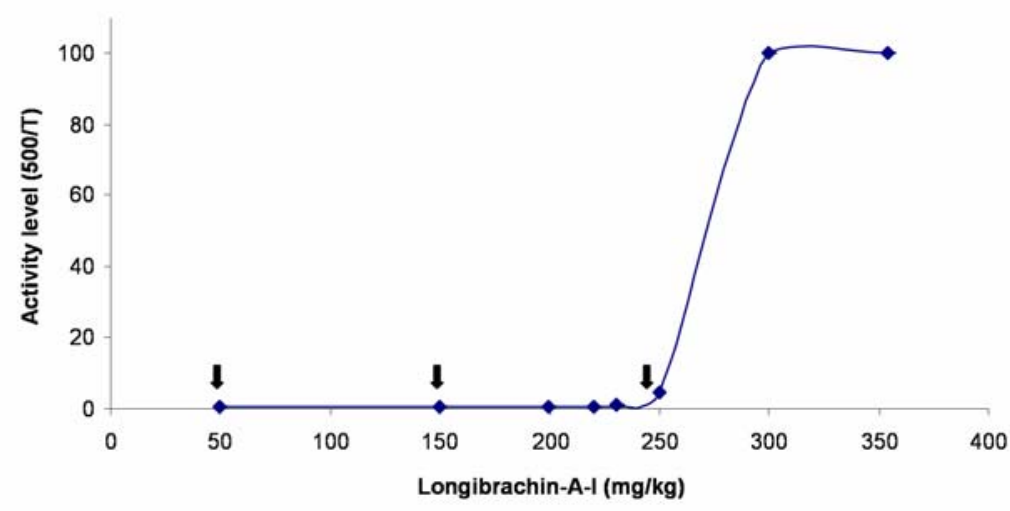

Fig. 1. Activity/dose curve of longibrachin-A-I on Diptera larvae. Black arrows indicate the concentrations used for the study of potentiation of domoic acid toxicity by addition of constant doses of longibrachinA-I.

\subsection{Combined toxicity of domoic acid with longibrachin-A-I}

To study the combined toxicity of domoic acid and longibrachin-A-I, ranges of dilutions of a domoic acid solution with addition of constant concentrations of longibrachin-A-I were tested. Three concentrations (black arrows on Fig. 1) were selected from the activity/dose curve of longibrachin-A-I corresponding to the MED (250 mg/kg) and two infra-MED doses (150 and $50 \mathrm{mg} / \mathrm{kg}$ ). Dose/activity curves expressed in domoic acid concentrations are given in Fig. 2.

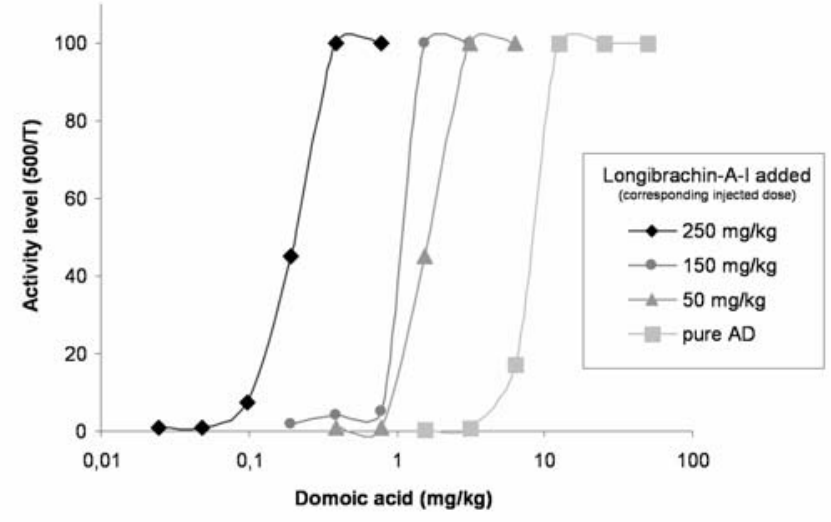

Fig. 2. Dose/activity curves of domoic acid with addition of different concentrations of longibrachin-A- I (black arrows of Fig 1.). All points are calculated with median values of 3 replicates.

ED50 obtained and corresponding calculated synergism factor (SF) as defined by Novelli et al. (1992a), are given in Table 2. The results showed an evident effect of potentiation with a high logarithmic correlation $\left(r^{2}=0,988\right)$ between $\mathrm{ED}_{50}$ of domoic acid and added doses of longibrachin-A-I. 
Table 2. $E D_{50}$ observed and corresponding calculated synergism factor (SF) for the potentiation of neurotoxicity of domoic acid (DA) by longibrachin-A-I (L$A-I)$. $\mathrm{SF}=\mathrm{ED}_{50}(\mathrm{DA}) / \mathrm{ED}_{50}(\mathrm{DA}+\mathrm{L}-\mathrm{A}-\mathrm{I})$

\begin{tabular}{lcc}
\hline & $\begin{array}{c}E D_{50} \\
\mathrm{mg} / \mathrm{kg}\end{array}$ & $\begin{array}{c}\text { Synergism } \\
\text { factor (SF) }\end{array}$ \\
\hline DA alone & 7.6 & - \\
$\mathrm{DA}+\mathbf{5 0} \mathbf{~ m g / k g ~ L - A - I ~}$ & $1.8 \pm 0.6$ & 4.2 \\
$\mathrm{DA}+\mathbf{1 5 0} \mathbf{~ m g / k g ~ L - A - I ~}$ & $1.2 \pm 0.05$ & 6.3 \\
$\mathrm{DA}+\mathbf{2 5 0} \mathbf{~ m g / k g ~ L - A - I ~}$ & $0.22 \pm 0.068$ & 34.5 \\
\hline
\end{tabular}

\section{Discussion}

\subsection{Acute toxicity on Diptera larvae}

Acute toxicity on Diptera larvae has been used in different ways for different purposes but always to detect a neurotoxicity. First use was injection in larvae for detection of toxins in scorpion venom (Zlotkin et al., 1971). For that purpose, the test was considered positive if larvae were immobilized for at least $5 \mathrm{~s}$. Zdarek and Fraenkel (1987) observed pupariation of the larvae after administration of toxic compounds to evaluate toxicity. Labrousse and Matile (1996) gave toxic moray eel flesh for breeding Diptera larvae of different species to detect ciguatoxin. Death or immobilization of larvae were observed and larvae were weighed after $24 \mathrm{~h}$ of breeding. This protocol was also tested with various other toxins such as tetrodotoxin and okadaic acid for marine toxins, and amanitin or aflatoxin B1 for fungal toxins. They observed toxicities which were expressed by a detection limit per $\mathrm{g}$ of contaminated fish flesh but the exact amount of toxin ingested by each larva could only be estimated. Direct injection into the larva can solve the problem of exact injected quantities. This is essential to evaluate toxicities of tested compounds. Furthermore, as fly larva can be described as a watertight bag containing an haemolymph liquid in which all organs are floating, compounds injected into the heamolymph will reach all structures, specially neurons and nervous ganglion, without any barrier to cross or chemical transformation to be subjected to.

\subsection{Potentiation of domoic acid toxicity}

Domoic acid has been described to be a potent agonist for kainate and AMPA subclasses of ionotropic non- $\mathrm{N}$ methyl-D-aspartate (non-NMDA) glutamate receptors (Hampson and Manalo, 1998) and has been classified as an excitatory amino acid (EAA) (Novelli et al., 1992b). Indeed, domoic acid increases the release of EAA such as glutamate after activation of non-NMDA receptors and the EAA efflux activates NMDA receptors secondarily involving calcium influx into the cell (Terrian et al., 1991; Berman et al., 1997). Moreover, domoic acid was also described to activate directly NMDA receptors involving calcium influx into the cell (Tasker et al., 2005). Both activation of NMDA and non-NMDA receptors induce membrane depolarisation which activates voltage sensitive calcium channels of L-type, increasing calcium intake (Berman et al., 2002). Direct activation of voltagedependant calcium channels to promote influx of calcium was also reported by Brown and Nijjar (1995).

Peptaibols form a large group of amphiphilic, non-ribosomal peptide antibiotics, which are rich in the nonproteinogenic $\alpha$-aminoisobutyric acid (Aib) (Degenkolb et al., 2008). The peptaibol backbone generally forms an amphipathic helical structure due to the conformational constraints imposed by the Aib residues. Their helical structures allow peptaibols to interact with natural and artificial bilayers increasing membrane permeability (Rebuffat et al., 1999; Peltola et al., 2004; Whitmore and Wallace, 2004). Peptaibols are known to form pores similar to endogenous sensitive calcium channels, involving calcium influx into the cell. They also activate voltage sensitive calcium channel of L-type, involving a $\mathrm{Ca}^{2+}$ influx into the cell (Tachikawa et al., 1991; Huang et al., 1994; Grigoriev et al., 1995; Wada et al., 1996).

Potentiation level observed was higher than that described by Novelli et al. (1992a and 1992b) with glutamic acid: even with the lower dose tested of longibrachin-A-I $(50 \mathrm{mg} / \mathrm{kg})$ which gave a synergism factor of 4.2 where glutamic acid gave only 3.5. Domoic acid and longibrachin-A-I both contribute to an intake of $\mathrm{Ca}^{2+}$ into the cell. Potentiation could then result of a magnified increase of intracellular $\mathrm{Ca}^{2+}$ concentration. Nevertheless to verify it, cellular and electro-physical experiments should be realized.

\section{Conclusion}

A potentiation of domoic acid activity on Diptera larvae by longibrachin-A-I was observed. To go further in this potentiation phenomenon, it would be necessarily to study the combined effect of domoic acid and peptaibols in mice. It would also be interesting to study combine effects of peptaibols (as longibrachin-A-I) with emerging 
marine toxins such as spirolids, cyclic imine toxins which would exert their toxic effects through alteration of ion conductance at the level of the plasma membrane (primarily $\mathrm{Ca}^{2+}$ ), acting on some acetylcholine receptors (Gill et al., 2003; Cembella and Krock, 2008).

\section{Acknowledgements}

Authors want to thank Thibaut Robiou-du-Pont, Alan Hegron, Xavier Reculeau and Armelle DenardouQueneherve for their technical help, and Philip Hess for reviewing the English language. This work has been supported by Region Pays de la Loire (France) through the research program GERRICO.

\section{References}

Amzil, Z., Marcaillou-Le Baut, C., Bohec, M., 1996. Unexplained toxicity in molluscs gathered during phytoplankton monitoring. In: Yasumoto, T., Oshima, Y., Furuyo, Y. (Eds.), Harmful and Toxic Algal Blooms, Int. Oceanogr. Com. of Unesco, pp. 543-546.

Bates, S., 1989. Pennate diatom Nitzschia pungens as the primary source of domoic acid, a toxin in shellfish from eastern Prince Edward Island, Canada. Can. J. Fish. Aquat. Sci. 46, 1203-1215.

Berman, F.W., Murray, T.F., 1997. Domoic acid neurotoxicity in cultured cerebellar granule neurons is mediated predominantly by NMDA receptors that are activated as a consequence of excitatory amino acid release. J. Neurochem. 69, 693-703.

Berman, F.W., LePage, K.T., Murray, T.F., 2002. Domoic acid neurotoxicity in cultured cerebellar granule neurons is controlled preferentially by the NMDA receptor $\mathrm{Ca}^{2+}$ influx pathway. Brain Res. 924, 20-29.

Brewer, D., Greenwell, M., Taylor A., 1993. Studies of Trichoderma isolates from Mytilus edulis collected on the shores of Cape Breton and Prince Edward Island. Proc. N. S. Inst. Sci. 40, 29-40.

Brown, J.A., Nijjar, M.S., 1995. The release of glutamate and aspartate from rat brain synaptosomes in response to domoic acid (amnesic shellfish toxin) and kainic acid. Mol. Cell. Biochem. 151, 49-54.

Brückner, H., Przybylski, M., 1984. Methods for the rapid detection, isolation and sequence determination of peptaibols and other Aib-containing peptides of fungal origin. I. Gliodesquin A from Gliocladium deliquescens. Chromatographia 19, 188-199.

Burdock, G.A., Carabin, I.G., Soni, M.G., 2001. Safety assessment of B-nitropropionic acid: a monograph in support of an acceptable daily intake in humans. Food Chem. 75, 1-27.

Cembella, A.D., Krock, B., 2008. Cyclic imine toxins: chemistry, biogeography, biosynthesis and pharmacology. In: Botana L.M. (Ed.), Seafood and Freshwater Toxins, Pharmacology, Physiology and Detection. Taylor \& Francis Ltd, Boca Raton, 561-580.

Degenkolb, T., von Döhren, H., Nielsen, C.F., Samuels, G.J., Brückner H., 2008. Recent advances and future prospects in peptaibiotics, hydrophobin, and mycotoxin research, and their importance for chemotaxonomy of Trichoderma and Hypocrea. Chem. Biodiv. 5, 671-680.

Gill, S., Murphy, M., Clausen, J., Richard, D., Quilliam, M., MacKinnon, S., La Blanc, P., Mueller, R., Pulido, O., 2003. Neural injury biomarkers of novel shellfish toxins, spirolides: a pilot study using immunochemical and transcriptional analysis. Neurotoxicology 24: 593-604.

Grigoriev, P., Schlegel, R., Dornberger, K., Gräfe, U., 1995. Formation of membrane channels by chrysospermins, new peptaibol antibiotics. Biochim. Biophys. Acta 1237, 1-5.

Grimmelt, B., Nijjar, M.S., Brown, J., Macnair, N., Wagner, S., Johnson, G.R., Amend, J.F., 1990. Relationship between domoic acid levels in the blue mussel (Mytilus edulis) and toxicity in mice. Toxicon 28, 501-508.

Hampson, D.R., Huang, X.P., Wells, J.W., Walter, J.A., Wright, J.L.C., 1992. Interaction of domoic acid and several derivatives with kainic acid and AMPA binding sites in rat brain. Eur. J. Pharmacol. 218, 1-8.

Hampson, D.R., Manolo, J.L., 1998. The activation of glutamate receptors by kainic acid and domoic acid. Nat. Toxins 6, 153-158. 
Huang, Q., Tezuka, Y., Kikuchi, T., Momose, Y., 1994. Trichokonin VI, a new Ca ${ }^{2+}$ channel agonist in bullfrog cardiac myocytes. Eur. J. Pharmacol. 271, R5-R6.

Huang, Q., Tezuka, Y., Hatanaka, Y., Kikuchi, T., Nishi, A., Tubaki, K., 1996. Studies on metabolites of mycoparasitic fungi. V. Ion-spray ionization mass spectrometric analysis of trichokonin II, a peptaibol mixture obtained from the culture broth of Trichoderma koningii. Chem. Pharm. Bull. 44, 590-593.

Kerzaon, I., Grovel, O., Monteau, F., Le Bizec, B., Nourisson, M.R., Biard, J.F., Pouchus, Y.F., in press. Structural investigation and elucidation of new communesins from marine-derived Penicillium expansum Link. by liquid chromatography/electrospray ionization ion trap tandem mass spectrometry. Rapid Commun. Mass Spectrom. (In press).

Labrousse, H., Matile, L., 1996. Toxicological biotest on Diptera larvae to detect ciguatoxins and various other toxic substances. Toxicon 34, 881-891.

Landreau, A., Pouchus, Y.F., Biard, J.F., Boumard, M.C., Sallenave-Namont, C., Robiou du Pont, T., Verbist J.F., 2002. Combined use of LC/MS and biological test during rapid identification of marine mycotoxins produced by Trichoderma koningii. J. Microbiol. Methods 48, 181-194.

Leclerc, G., Rebuffat, S., Goulard, C., Bodo, B., 1998. Directed biosynthesis of peptaibol antibiotics in two Trichoderma strains. I. Fermentation and isolation. J. Antibiot. 51, 170-177.

McKinley, E.R., Carlton, W.W., 1980. Patulin mycotoxicosis in Swiss ICR mice. Food Cosmet. Toxicol. 18, 181187.

Mohamed-Benkada, M., Montagu, M., Biard, J.F., Mondeguer, F. Verite, P., Dalgarondo, M., Bisset, J., Pouchus, Y.F., 2006. New short peptaibols from a marine Trichoderma strain. Rapid Commun. Mass Spectrom. 20, 1176-1180.

Novelli, A., Kispert, J., Fernandez-Sanchez, M.T., Torreblanca, A., Zitko, V., 1992a. Domoic acid containing toxic mussels produce neurotoxicity in neuronal cultures through a synergism between excitatory amino acid. Brain Res. 577, 41-48.

Novelli, A., Fernandez-Sanchez, M.T., Kispert, J., Torreblanca, A., Gascon, S., Zitko, V., 1992b. The amnesic shellfish poison domoic acid enhances neurotoxicity by excitatory amino acids in cultured neurons. Amino Acids 2, 233-244.

Peltola, J., Ritieni, A., Mikkola, R., Grigoriev, P.A., Pocsfalvi, G., Andersson, M.A., Salkinoja-Salonen, M.S., 2004. Biological effects of Trichoderma harzianum peptaibols on mammalian cells. Appl. Environ. Microbiol. 70, 4996-5004.

Poirier, L., Montagu, M., Landreau, A., Mohamed-Benkada, M., Grovel, O., Sallenave-Namont, C., Biard, J.F., Amiard-Triquet, C., Amiard, J.C., Pouchus, Y.F., 2007a. Peptaibols, stable markers of fungal contamination in the marine environment. Chem. Biodiv. 4, 1116-1128.

Poirier, L., Quiniou, F., Ruiz, N., Montagu, M., Amiard, J.C., Pouchus, Y.F., 2007b. Toxicity assessment of peptaibols and contaminated sediments on Crassostrea gigas embryos. Aquat. Toxicol. 83, 254-262.

Pulido, O.M., 2008. Domoic acid toxicologic pathology: a review. Mar. Drugs 6, 180-219.

Rebuffat, S., Goulard, C., Bodo, B., Roquebert, M.F., 1999. The peptaibols antibiotics from Trichoderma soil fungi: structural diversity and membrane properties. Recent Res. Devel. Org. Bioorg. Chem 3, 65-91.

Ruiz, N., Wielgosz-Collin, G., Poirier, L., Grovel, O., Petit, K.E., Mohamed-Benkada, M., Robiou du Pont, T., Bisset, J., Barnathan, G., Pouchus, Y.F., 2007. New trichobrachins, 11-residue peptaibols from a marine strain of Trichoderma longibrachiatum. Relation hydrophobicity / cytotoxicity. Peptides 28, 1351-1358.

Sallenave, C., Pouchus, Y.F., Bardouil, M., Lassus, P., Roquebert, M.F., Verbist, J.F., 1999. Bioaccumulation of mycotoxins by shellfish : contamination of mussels by metabolites of a Trichoderma koningii strain isolated in the marine environment. Toxicon $37,77-83$.

Sallenave-Namont, C., Pouchus, Y.F., Robiou du Pont, T., Lassus, P., Verbist, J.F., 2000. Toxigenic saprophytic fungi in marine shellfish farming areas. Mycopathologia 149, 21-25. 
Selwood, A.I., Ginkel, R., Wilkins, A.L., Munday, R., Ramsdell, J.S., Jensen, D.J., Cooney, J.M., Miles, C.O., 2008. Semisynthesis of S-desoxybrevetoxin-B2 and brevetoxin-B2, and assessment of their acute toxicities. Chem. Res. Toxicol. 21, 944-950.

Smith, J.C., 1993. Toxicity and Pseudo-nitzschia pungens in Prince Edward Island, 1987-1992. Harmful Algae News 6, 1-8.

Tachikawa, E., Takahashi, S., Furumashi, K., Kashimoto, T., lida, A., Nagaoka, Y., Fujita, T., Takaishi, Y., 1991. Trichosporin B-III, an alpha-aminoisobutyric acid containing peptide, causes $\mathrm{Ca}^{2+}$ dependant catecholamine secretion from adrenal medullary chromaffin cells. Mol. Pharmacol. 40, 790-797.

Tasker, R.A.R., Perry, M.A., Doucette, T.A., Ryan C.L., 2005. NMDA receptor involvement in the effects of low dose domoic acid in neonatal rats. Amino Acids 28, 193-196.

Terrian, D.M., Conner Kerr, T.A., Privette, T.H., Gannon, R.L., 1991. Domoic acid enhances the K+evoked release of endogenous glutamate from guinea pig hippocampal mossy fiber synaptosomes. Brain Res. 55 , 303-307.

Todd, E.C.D., 1993, Domoic acid and amnesic shellfish poisoning: a review. J. Food Protect. 56, 68-83.

Wada. S.I., lida, A., Asami, K., Fujita, T., 1996. Ion-channel forming property of trichorovin XII, an 11-residue peptaibol from the fungus Trichoderma viride, in planar lipid bilayers membranes. Bioorg. Med. Chem. Lett. 6, 2275-2278

Waterhouse, A.L., Pessah, I.N., Francini, A.O., Casida, J.E., 1987. Structural aspects of ryanodine action and selectivity. J. Med. Chem. 30, 710-716.

Wekell, J.C., Gauglitz, E.J.Jr., Barnett, H.J., Hatfield, C.L., Simons, D., Ayres D., 1994. Occurrence of domoic acid in Washington state razor clams (Siliqua patula) during 1991-1993. Nat Toxins 2, 197-205.

Whitmore, L., Wallace, B.A., 2004. Analysis of peptaibol sequence composition: implications for in vivo synthesis and channel formation. Eur. Biophys. J. 33, 233-237.

Wiberg, G.S., Stephenson, N.R., 1960. Toxicologic studies on paralytic shellfish poison. Toxicol. Appl. Pharmacol. 2, 607-615.

Wright, J.L.C., Boyd, R.K., Defreitas, A.S.W., Falk, M., Foxall, R.A., Jamieson, W.D., Laycock, M.V., Mc Mulloch, A.W., Mc Innes, A.G., Odense, P., Pathak, V., Quilliam, M.A., Ragen, M., Sim, P.G., Thibault, P., Walter, J.A., Gilgan, M., Richard, D.J.A., Dewar, D., 1989. Identification of domoic acid, a neuroexcitatory amino acid, in toxic mussels from eastern P.E.I. Can. J. Chem. 67, 481-490.

Xu, Q., Huang, K., Gao, L., Zhang, H., Rong, K., 2003. Toxicity of tetrodotoxin towards mice and rabbits. J. Hyg. Res. (Wei Sheng Yan Jiu) 32, 371-374.

Zdarek, J., Fraenkel, G., 1987. Pupariation in flies: a tool for monitoring effects of drugs, venoms, and other neurotoxic compounds. Arch. Insect Biochem. Physiol. 4, 29-46.

Zlotkin, E., Fraenkel, G., Miranda, F., Lissitzki, S., 1971. The effect of scorpion venom on blowfly larvae - a new method for the evaluation of scorpion venoms potency. Toxicon 9, 1-8. 